Check for updates

Cite this: Phys. Chem. Chem. Phys., 2021, 23, 25278

Received 20th August 2021

Accepted 28th October 2021

DOI: $10.1039 / \mathrm{d} 1 \mathrm{cp} 03828 \mathrm{a}$

rsc.li/pccp

\section{Electrochemical switching of positronium triplet quenching $\dagger$}

\author{
Philipp Brunner, (D) * Eva-Maria Steyskal (D) and Roland Würschum (DD
}

Switching of positronium triplet quenching could successfully be demonstrated by electrochemical means in an aqueous $\mathrm{K}_{3}\left[\mathrm{Fe}(\mathrm{CN})_{6}\right]$ electrolyte. For this purpose a suitable cell was designed to combine positron annihilation with electrochemical measurements. Highly reversible substantial variations of the mean positron lifetime $\tau_{\mathrm{m}}$ could be observed upon electrochemical switching between the oxidation states $\mathrm{Fe}(\mathrm{CN})_{6}{ }^{3-}$ and $\mathrm{Fe}(\mathrm{CN})_{6}{ }^{4-}$, arising from oxidation of positronium by $\mathrm{Fe}(\mathrm{CN})_{6}{ }^{3-}$. Dynamic in situ measurements in dependence of potential exhibit a hysteresis like behavior of $\tau_{\mathrm{m}}$ which perfectly correlates with the shift between the reduction and oxidation peaks simultaneously monitored by cyclic voltametry.

\section{Introduction}

In situ measurement techniques allow direct monitoring of chemical and physical processes taking place on a microscopic scale in the sample of interest. So far, methods like X-ray and neutron diffraction, scanning probe and electron microscopy, optical techniques like Raman spectroscopy, or magnetometry are used especially in electrochemistry to investigate in situ, e.g., energy storage materials. ${ }^{1,2}$ Recently, our group introduced positron annihilation as in situ tool and demonstrated first operando positron lifetime measurements under full electrochemical control to study charging-induced defects in battery electrodes. ${ }^{3}$ In this work we further expand the application of positron annihilation and monitor for the first time in situ the switching of triplet quenching in aqueous electrolytes by electrochemical means.

Positron and positronium chemistry has a wide area of application in analytical, organic, inorganic and physical chemistry, ${ }^{4,5}$ where, e.g., different kinds of solutions, polymers like polyethylene or porous materials such as zeolites are investigated. ${ }^{6-9}$ Positronium (Ps), a highly sensitive chemical probe, is a hydrogen-like bound state of an electron $\left(\mathrm{e}^{-}\right)$and a positron $\left(\mathrm{e}^{+}\right)$, which either forms in the singlet state (para-Ps), with opposite spin direction of $\mathrm{e}^{-}$and $\mathrm{e}^{+}$, or in the triplet state (ortho-Ps) with spin-parallel configuration. para-Ps undergoes rapid annihilation in two $\gamma$-quanta with a short lifetime of 125 ps in vacuum, whereas ortho-Ps due to annihilation in three $\gamma$-quanta exhibits a much longer lifetime of about $140 \mathrm{~ns}$. In condensed matter, $\mathrm{e}^{+}$of ortho-Ps undergoes so-called pick-off

Institute of Materials Physics, Graz University of Technology, Petersgasse 16, 8010 Graz, Austria. E-mail: philipp.brunner@tugraz.at

$\dagger$ Electronic supplementary information (ESI) available. See DOI: 10.1039/d1cp03828a annihilation with an electron of the surrounding molecules having opposite spin direction, which results in a two $\gamma$-annihilation with drastically reduced lifetime in the range 1 to $5 \mathrm{~ns}$ compared to the lifetime of ortho-Ps in vacuum. Furthermore, Ps is able to react with solved ions in aqueous solutions, e.g., via Ps oxidation, bound-state formation, or spin conversion, which also results in a reduction of the ortho-Ps lifetime. Beside these so called quenching mechanisms, some solutes also inhibit the Ps formation, which causes a decrease in the measured ortho-Ps intensity. ${ }^{4,5}$

Up to now, only ex situ positron annihilation studies have been performed in aqueous solutions. One particularly interesting species is the $\mathrm{Fe}(\mathrm{CN})_{6}{ }^{3-/ 4-}$ redox couple, ${ }^{10}$ used for a proof of concept in this work. $\mathrm{Fe}(\mathrm{CN})_{6}{ }^{3-}$ ions effectively oxidize Ps and, therefore, rapidly decrease the ortho-Ps lifetime, whereas in the reduced $\mathrm{Fe}(\mathrm{CN})_{6}{ }^{4-}$ state, a negligible quenching reaction and, therefore, a significantly longer Ps lifetime compared to $\mathrm{Fe}(\mathrm{CN})_{6}{ }^{3-}$ occurs. ${ }^{11-14}$ The present work aims at in situ control and monitoring of Ps quenching by electrochemically switching between these two oxidation states $\left(\mathrm{Fe}(\mathrm{CN})_{6}{ }^{3-} \leftrightarrow\right.$ $\left.\mathrm{Fe}(\mathrm{CN})_{6}{ }^{4-}\right)$ and simultaneously measuring the $\mathrm{e}^{+}$lifetime.

\section{Experimental}

\subsection{Electrochemical Cell}

To combine electrochemical measurements with positron lifetime spectroscopy, a suitable cell set-up was designed (see Fig. 1). As shown in figure part a, the cell consists of two identically constructed sub-cells (upper and lower part), made mainly of polyetheretherketone (PEEK). Between these two subcells the $\mathrm{e}^{+}$source is placed (for more details see Section 2.2). The whole cell set-up is mounted between the detectors of the 
(a)

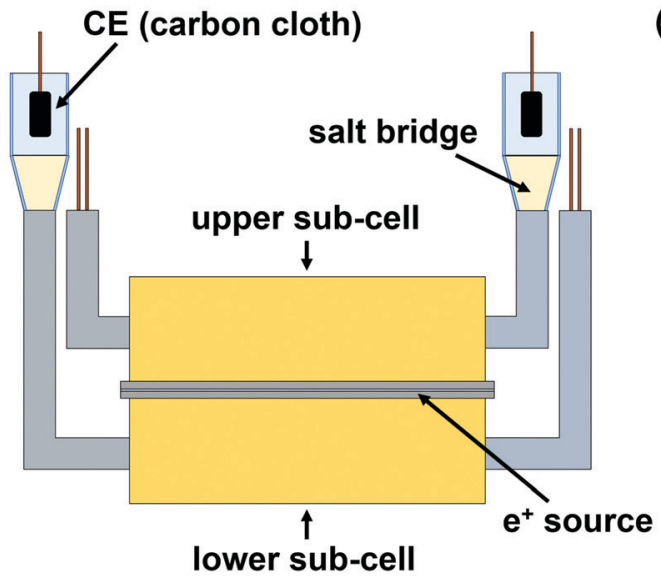

(b) PTFE and

\section{embedding medium}

to fix WE $\quad \mathrm{e}^{+} \quad$ window for $\mathrm{e}^{+}$

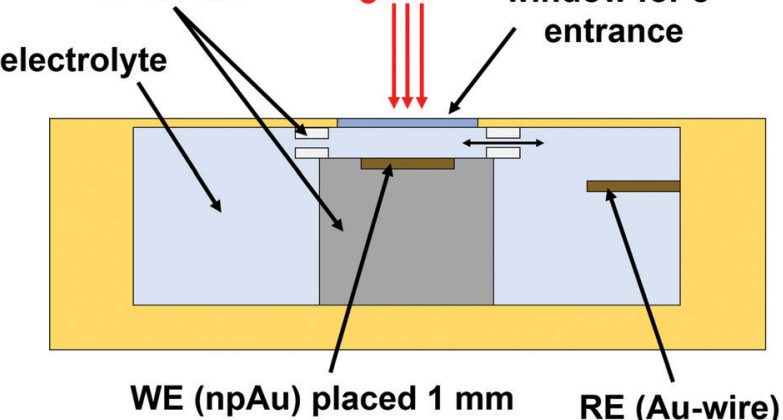

away from window

Fig. 1 Cell designed to combine electrochemical with positron lifetime measurements. (a) The cell consists of two identically constructed sub-cells (upper and lower part). The counter electrode (CE) is connected via a salt bridge to the cell. Between the two sub-cells, the $\mathrm{e}^{+}$source is placed. (b) Assembling inside the sub-cell showing the window for $\mathrm{e}^{+}$entrance, the working electrode (WE), and the gold reference electrode (RE). $\mathrm{e}^{+}$annihilation occurs in the $1 \mathrm{~mm}$ thick electrolyte layer above the WE.

positron lifetime spectrometer. The counter electrode (CE) is connected via a salt bridge to the sub-cell. On the CE side $0.1 \mathrm{~mol} \mathrm{~L}^{-1} \mathrm{KCl}$ was used as electrolyte.

The assembling inside the sub-cell is depicted in Fig. 1b. The window for $\mathrm{e}^{+}$entrance consists of a $15 \mu \mathrm{m}$ thick hostaphan foil. The working electrode (WE), fixed between two PTFE pieces, is placed $1 \mathrm{~mm}$ away from the $\mathrm{e}^{+}$entrance window in order to ensure that $\mathrm{e}^{+}$annihilate quantitatively in the electrolyte. For electrolyte exchange, the PTFE pieces contain gaps. The reference electrode (RE) is placed next to the WE.

2.1.1 Chemicals and materials. Potassium hexacyanoferrate(III) $\mathrm{K}_{3}\left[\mathrm{Fe}(\mathrm{CN})_{6}\right](\geq 99 \%$, techn.), potassium hexacyanoferrate(II) trihydrate $\mathrm{K}_{4}\left[\mathrm{Fe}(\mathrm{CN})_{6}\right](\geq 98.5 \%$, krist.), potassium hydroxide $\mathrm{KOH}(\geq 85 \%)$, potassium chloride $\mathrm{KCl}$ ( $\geq 99.5 \%$ ) and $1 \mathrm{~mol} \mathrm{~L}^{-1} \mathrm{H}_{2} \mathrm{SO}_{4}$ were obtained from Carl Roth, $1 \mathrm{~mol} \mathrm{~L}^{-1}$ perchloride acid $\mathrm{HClO}_{4}$ from Sigma Aldrich. KOH, $\mathrm{KCl}, \mathrm{H}_{2} \mathrm{SO}_{4}$ and $\mathrm{HClO}_{4}$ were dissolved or diluted, respectivley, to the desired concentration in highly pure water (ROTIPURAN p.a., ACS, Carl Roth). $\mathrm{K}_{3}\left[\mathrm{Fe}(\mathrm{CN})_{6}\right]$ and $\mathrm{K}_{4}\left[\mathrm{Fe}(\mathrm{CN})_{6}\right]$ were freshly prepared before each measurement by dissolving the desired concentration in $1 \mathrm{mmol} \mathrm{L}^{-1} \mathrm{KOH}$.

An AuAg (25at\%75at\%) alloy was produced by arc melting pieces of silver wire (0.5 mm diameter, $99.9 \%$, chemPUR) and gold granules ( $99.99 \%$, chemPUR) in corresponding mass ratio. A Mini Arc Melter MAM 1 from the Edmund Bühler GmbH was used as arc melter.

2.1.2 Salt bridge preparation. Glass pasteur pipettes (Carl Roth) were cut to the desired length. $10 \mathrm{ml}$ of high purity water was heated to $100{ }^{\circ} \mathrm{C}$ and $3.33 \mathrm{~g} \mathrm{KCl}$ and $0.75 \mathrm{~g}$ Agar-Agar (Kobe I pulv., Carl Roth) were dissolved in it. The hot mixture was then drawn up a few centimeters in the glass pipettes. After cooling down to room temperature the salt bridges, prepared in this way, were stored in $0.1 \mathrm{~mol} \mathrm{~L}^{-1} \mathrm{KCl}$. No salt bridges older than five days were used for the measurements.

2.1.3 Electrodes. As working electrodes (WE) nanoporous gold (npAu) electrodes were used to provide a large area of electrode-electrolyte interface. Two identical electrodes were prepared as follows: a flattened gold wire $(0.25 \mathrm{~mm}$ diameter, 99.9\%, chemPUR) was diffusion bonded to the AuAg (25 at\% 75 at\%) alloy $(5 \mathrm{~mm} \times 5 \mathrm{~mm} \times 200 \mu \mathrm{m})$ in a vacuum furnace (Pfeiffer Vacuum) at $400{ }^{\circ} \mathrm{C}$. The backside of the contacted AuAg alloy was subsequently embedded in Thermokitt (Carl Roth) and dried at room temperature and $250{ }^{\circ} \mathrm{C}$ in air. Upon electrochemically dealloying ${ }^{15}$ the $\mathrm{AuAg}$ alloy in $0.1 \mathrm{~mol} \mathrm{~L}^{-1} \mathrm{HClO}_{4}$ at a potential of $1150 \mathrm{mV}$ (versus a commercial $\mathrm{Ag} / \mathrm{AgCl}$ reference electrode, $3 \mathrm{~mol} \mathrm{~L}^{-1} \mathrm{KCl}$ with $3 \mathrm{~mol} \mathrm{~L}^{-1}$ $\mathrm{KNO}_{3}$ salt bridge), a nanoporous structure evolves. Subsequently the npAu electrode was cycled in $0.1 \mathrm{~mol} \mathrm{~L}^{-1} \mathrm{H}_{2} \mathrm{SO}_{4}$ with a scan rate of $0.5 \mathrm{mV} \mathrm{s}^{-1}$ between 200 and $1450 \mathrm{mV}$ (versus $\mathrm{Ag} / \mathrm{AgCl}$ ) until the electrode is in a well-reduced and steady state. The npAu electrode was finally coarsened in vacuum at $250{ }^{\circ} \mathrm{C}$ for $10 \mathrm{~h}$ to a ligament size of $50-80 \mathrm{~nm}$ (determined according to literature ${ }^{16,17}$ ).

As reference electrodes (RE) gold wires, as counter electrodes (CE) carbon cloths connected to gold wires were used. All given potentials refer to the gold RE.

\subsection{Measurement devices}

The $\mathrm{e}^{+}$lifetime measurements were performed with an analogous fast-fast positron lifetime spectrometer with a time resolution of 165 ps. For a more detailed description of the measurement set-up see, e.g., Keeble et al. ${ }^{18}$ The $\mathrm{e}^{+}$source consists of ${ }^{22} \mathrm{NaCl}$ encapsulated between $5 \mu \mathrm{m}$ thick Al foils. For protecting the $\mathrm{e}^{+}$source, it was covered on both sides by a $15 \mu \mathrm{m}$ thick Hostaphan foil and clamped between two Al frames. Spectra were recorded for $30 \mathrm{~min}$ and subsequently summed up. The total amount of counts of the final spectrum depend on the type of measurement done (for more details see Section 2.3). The recorded spectra were analyzed via a three components fit after source and Hostaphan foil correction by means of the program PALSFIT. ${ }^{19}$ A silicon reference sample was used to determine the contribution of the source and the 
Hostaphan foil consisting of two components of 465 ps and 1700 ps with relative intensities of $10 \%$ and $3 \%$. For this purpose in the common sample-source-sample set-up two Hostaphan foils were placed between the source $\left({ }^{22} \mathrm{NaCl}-\mathrm{Al}\right.$ foil arrangement) and the sample. A detailed description of the fitting models used by PALSFIT, including the determination of numerical uncertainties, is given by Kirkegaard et $a l^{20}$ Due to the correlations of the lifetime components $\tau_{i}$ and their relative intensities $I_{i}$, the covariance matrix is used to estimate the numerical uncertainty of the mean $\mathrm{e}^{+}$ lifetime $\tau_{\mathrm{m}}$ (see eqn (97) in ref. 20).

For the electrochemical measurements an AUTOLAB potentiostat (AUT50611, METROHM) and the NOVA 1.11 software were used.

\subsection{Measurement procedures}

Table 1 lists the electrolytes used for the different types of measurements. An alkaline environment was chosen to avoid the formation of prussian blue. ${ }^{21,22}$

2.3.1 Beaker-measurements. The cyclic voltammograms (CVs) were recorded in a beaker between -400 and $200 \mathrm{mV}$ with a scan rate of $5 \mathrm{mV} \mathrm{s}^{-1}$. The common three electrode setup (WE, RE, CE) was chosen, as described in literature. ${ }^{23}$ The CE was connected via a salt bridge to the beaker to have a similar set-up as used for the electrochemical cell. On the CE side $0.1 \mathrm{~mol} \mathrm{~L}^{-1} \mathrm{KCl}$ was used as electrolyte.

2.3.2 In situ $\mathrm{e}^{+}$-measurements. The electrochemical cell set-up (described in Section 2.1) was placed between the detectors of the positron lifetime spectrometer. To check if the sub-cells worked properly, each sub-cell was connected individually to the potentiostat and a $\mathrm{CV}$ between -400 and $200 \mathrm{mV}$ with two cycles and a scan rate of $2 \mathrm{mV} \mathrm{s}^{-1}$ was recorded. A comparison of a $\mathrm{CV}$ taken in the cell set-up and in a beaker is given in the ESI. $\dagger$ For the measurement, the two sub-cells were connected in parallel to the potentiostat. For this set-up, a further CV was taken (two cycles between -400 and $200 \mathrm{mV}$ with a scan rate of $2 \mathrm{mV} \mathrm{s}^{-1}$ ).

The static in situ studies were performed with applied voltages of $150 \mathrm{mV}$ and $-350 \mathrm{mV}$ measuring for $9.5 \mathrm{~h}$ in the case of $\mathrm{K}_{3}\left[\mathrm{Fe}(\mathrm{CN})_{6}\right]$ with $1 \mathrm{mmol} \mathrm{L}{ }^{-1} \mathrm{KOH}$ and for $8 \mathrm{~h}$ in the case of $1 \mathrm{mmol} \mathrm{L}^{-1} \mathrm{KOH}$ reference. The potential was varied with a scan rate of $2 \mathrm{mV} \mathrm{s}^{-1}$ upon switching in order to prevent potential jumps. A cutout of the measurement procedure is given in the ESI. $\dagger$ During the entire measurement sequence, $\mathrm{e}^{+}$ lifetime spectra were recorded and the cell current was monitored. The first two $\mathrm{e}^{+}$lifetime subspectra at each potential were excluded. Spectra taken for $\mathrm{K}_{3}\left[\mathrm{Fe}(\mathrm{CN})_{6}\right]$ contain at least $4.0 \times 10^{5}$ counts, for $1 \mathrm{mmol} \mathrm{L}^{-1} \mathrm{KOH}$ reference at least $2.8 \times 10^{5}$ counts.

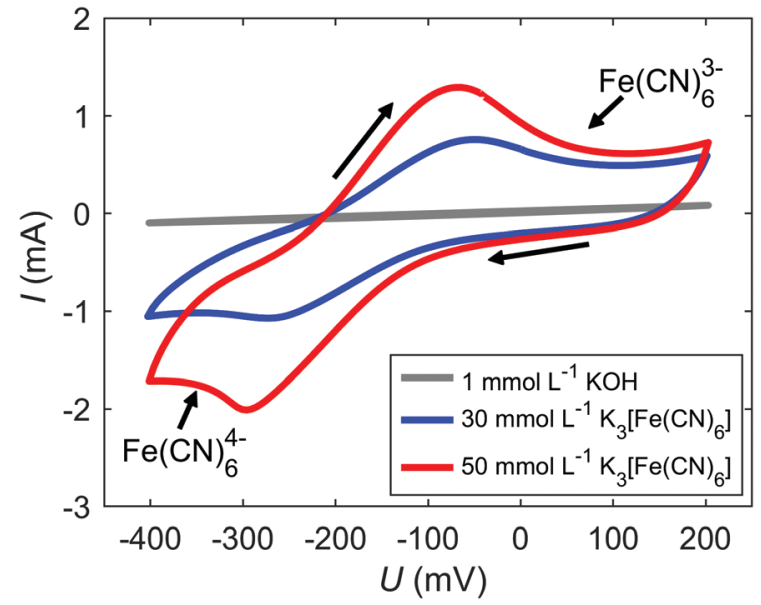

Fig. 2 Cyclic voltammograms (CVs) of $1 \mathrm{mmol} \mathrm{L}^{-1} \mathrm{KOH}$ (gray), of $30 \mathrm{mmol} \mathrm{L}^{-1}$ $\mathrm{K}_{3}\left[\mathrm{Fe}(\mathrm{CN})_{6}\right]$ with $1 \mathrm{mmol} \mathrm{L}^{-1} \mathrm{KOH}$ (blue), and of $50 \mathrm{mmol} \mathrm{L}^{-1} \mathrm{~K}_{3}\left[\mathrm{Fe}(\mathrm{CN})_{6}\right]$ with $1 \mathrm{mmol} \mathrm{L}^{-1} \mathrm{KOH}$ (red) measured between -400 and $200 \mathrm{mV}$ with a scan rate of $5 \mathrm{mV} \mathrm{s}^{-1}$. The arrows indicate the scan direction. Note that these CVs were conducted in a beaker, where the npAu electrode served as working and a gold wire as reference electrode; the carbon cloth, which was used as counter electrode, was connected via the salt bridge to the beaker. On the counter electrode side $0.1 \mathrm{~mol} \mathrm{~L}^{-1} \mathrm{KCl}$ was used as electrolyte.

For the dynamic in situ measurement, a linear potential sweep with $2 \mathrm{mV} \mathrm{s}^{-1}$ was performed from the OCP value to $150 \mathrm{mV}$. Thereafter a CV with one cycle between -350 and $150 \mathrm{mV}$ and a scan rate of $5.6 \mu \mathrm{V} \mathrm{s}{ }^{-1}$ was conducted and simultaneously $\mathrm{e}^{+}$lifetime spectra were recorded. The significantly slower scan rate for this type of measurement, as compared to, e.g., the beaker measurement, is required in order to obtain a sufficient amount of counts per recorded spectra. Five 30 min spectra were summed up to one total spectrum with about $1.0 \times 10^{5}$ counts. Each of these total spectra corresponds to one $\tau_{\mathrm{m}}$ data point in Fig. 3. Each $\tau_{\mathrm{m}}$ data point is assigned to the potential value corresponding to the middle of the linear voltage sweep over the $2.5 \mathrm{~h}$ measuring time.

2.3.3 Ex situ $\mathrm{e}^{+}$-measurements. For a direct comparison with the in situ measurements, ex situ measurements were performed with the same cell set-up, including WE and RE, but without salt bridge, $\mathrm{CE}$ and connection to the potentiostat. The analysed spectra contained at least $9.0 \times 10^{5}$ counts.

\section{Results and discussion}

The electrochemical behavior of the $\mathrm{Fe}(\mathrm{CN})_{6}{ }^{3-/ 4-}$ redox couple is shown in Fig. 2. Cyclic voltammograms (CVs) of $30 \mathrm{mmol} \mathrm{L}^{-1}$ $\mathrm{K}_{3}\left[\mathrm{Fe}(\mathrm{CN})_{6}\right]$ and $1 \mathrm{mmol} \mathrm{L}^{-1} \mathrm{KOH}$ (blue), and of $50 \mathrm{mmol} \mathrm{L}^{-1}$

Table 1 Electrolytes used for the different types of measurements

\begin{tabular}{|c|c|c|c|c|}
\hline & Beaker & Static switch & Dynamic & Ex situ \\
\hline $1 \mathrm{mmol} \mathrm{L}^{-1} \mathrm{KOH}$ & $\mathrm{X}$ & $\mathrm{X}$ & & $\mathrm{X}$ \\
\hline $30 \mathrm{mmol} \mathrm{L}^{-1} \mathrm{~K}_{3}\left[\mathrm{Fe}(\mathrm{CN})_{6}\right]+1 \mathrm{mmol} \mathrm{L}^{-1} \mathrm{KOH}$ & $\mathrm{X}$ & $\mathrm{X}$ & $\mathrm{X}$ & $\mathrm{X}$ \\
\hline $50 \mathrm{mmol} \mathrm{L}^{-1} \mathrm{~K}_{3}\left[\mathrm{Fe}(\mathrm{CN})_{6}\right]+1 \mathrm{mmol} \mathrm{L}^{-1} \mathrm{KOH}$ & $\mathrm{X}$ & $\mathrm{X}$ & & $\mathrm{X}$ \\
\hline $30 \mathrm{mmol} \mathrm{L}^{-1} \mathrm{~K}_{4}\left[\mathrm{Fe}(\mathrm{CN})_{6}\right]+1 \mathrm{mmol} \mathrm{L}^{-1} \mathrm{KOH}$ & & & & $\mathrm{X}$ \\
\hline $50 \mathrm{mmol} \mathrm{L}^{-1} \mathrm{~K}_{4}\left[\mathrm{Fe}(\mathrm{CN})_{6}\right]+1 \mathrm{mmol} \mathrm{L}^{-1} \mathrm{KOH}$ & & & & $\mathrm{X}$ \\
\hline
\end{tabular}


$\mathrm{K}_{3}\left[\mathrm{Fe}(\mathrm{CN})_{6}\right]$ and $1 \mathrm{mmol} \mathrm{L}^{-1} \mathrm{KOH}$ (red) were recorded in a beaker. The shapes of the measured CVs correspond well to literature. ${ }^{10,24}$ Upon applying negative (cathodic) potentials and passing the reduction peak between -250 and $-300 \mathrm{mV}$, $\mathrm{Fe}(\mathrm{CN})_{6}{ }^{3-}$ reduces to $\mathrm{Fe}(\mathrm{CN})_{6}{ }^{4-}$. Changing the scan direction and applying positive (anodic) potentials leads to the reverse reaction, i.e., the oxidation of $\mathrm{Fe}(\mathrm{CN})_{6}{ }^{4-}$ to $\mathrm{Fe}(\mathrm{CN})_{6}{ }^{3-}$ upon passing the oxidation peak between -75 and $-50 \mathrm{mV}$. In the $\mathrm{CV}$ of the $1 \mathrm{mmol} \mathrm{L}^{-1} \mathrm{KOH}$ reference electrolyte (gray) no reduction and oxidation peaks are visible in contrast to the CVs of $30 \mathrm{mmol} \mathrm{L}^{-1}$ and $50 \mathrm{mmol} \mathrm{L}^{-1} \mathrm{~K}_{3}\left[\mathrm{Fe}(\mathrm{CN})_{6}\right]$, i.e., there are no detectable changes in the electrolyte or on the electrode surface in the applied potential range associated with $\mathrm{KOH}$.

As a first step, ex situ measurements (without applied potentials) of the $\mathrm{Fe}(\mathrm{CN})_{6}{ }^{3-/ 4-}$ redox couple and the $1 \mathrm{mmol} \mathrm{L}^{-1} \mathrm{KOH}$ reference solution are made with the cell set-up used for in situ measurements (set-up described in Fig. 1). In Table 2 the fitted mean $\mathrm{e}^{+}$lifetimes $\tau_{\mathrm{m}}$ and the $\mathrm{e}^{+}$lifetime components $\tau_{i}$ with relative intensities $I_{i}$ are shown. The ortho-Ps lifetimes $\tau_{3}$ for 30 and $50 \mathrm{mmol} \mathrm{L}^{-1} \mathrm{~K}_{4}\left[\mathrm{Fe}(\mathrm{CN})_{6}\right]$ ranging from 1810 to 1830 ps correspond very well to the values of about 1800 ps reported in literature. ${ }^{11}$ In contrast to $\mathrm{Fe}(\mathrm{CN})_{6}{ }^{4-}, \mathrm{Fe}(\mathrm{CN})_{6}{ }^{3-}$ strongly oxidizes Ps and, therefore, drastically reduces $\tau_{3}{ }^{11-14}$ The intensities for the $\tau_{3}$ components are fixed in the fitting procedure, since according to Duplatre et al. ${ }^{11} \mathrm{a}$ similar Ps inhibition behavior can be expected for both oxidation states. A fit with fixed $I_{3}$ gives $\tau_{3}$ components with 996 and 789 ps for 30 and $50 \mathrm{mmol} \mathrm{L}^{-1} \mathrm{~K}_{3}\left[\mathrm{Fe}(\mathrm{CN})_{6}\right]$ respectively, in good accordance with 865 and 645 ps given in literature. ${ }^{11}$ For the sake of completeness and for reasons of traceability the fitting results for $\mathrm{K}_{3}\left[\mathrm{Fe}(\mathrm{CN})_{6}\right]$ with unfixed $I_{3}$ components are given in Table 2. Without fixation, smaller $I_{3}$ and longer $\tau_{3}$ values were determined for $\mathrm{K}_{3}\left[\mathrm{Fe}(\mathrm{CN})_{6}\right]$, which may arise from analysis uncertainties due to strong numerical correlations between $I_{3}$ and $\tau_{3}$.

The observed $\tau_{3}$-variation is considered to arise exclusively from $\mathrm{Fe}(\mathrm{CN})_{6}{ }^{3-}$ and $\mathrm{Fe}(\mathrm{CN})_{6}{ }^{4-}$, since both $\mathrm{OH}^{-}$ions at low concentrations and $\mathrm{K}^{+}$counterions show negligible quenching and inhibition properties. ${ }^{25,26}$. The fitted $\tau_{1}$ and $\tau_{2}$ components for $1 \mathrm{mmol} \mathrm{L}^{-1} \mathrm{KOH}, \mathrm{K}_{3}\left[\mathrm{Fe}(\mathrm{CN})_{6}\right]$ and $\mathrm{K}_{4}\left[\mathrm{Fe}(\mathrm{CN})_{6}\right]$, as well as the $\tau_{3}$ component for $1 \mathrm{mmol} \mathrm{L}^{-1} \mathrm{KOH}$ correspond well to values found in literature for pure water. ${ }^{8,27}$

The mean $\mathrm{e}^{+}$lifetimes $\tau_{\mathrm{m}}\left(=\sum_{i} \tau_{i} I_{i}\right)$ also shown in Table 2 reflect the variation of the Ps component $\tau_{3}$. The reduction in $\tau_{\mathrm{m}}$ for $\mathrm{K}_{3}\left[\mathrm{Fe}(\mathrm{CN})_{6}\right]$ (388 and $360 \mathrm{ps}$ ) compared to $\mathrm{K}_{4}\left[\mathrm{Fe}(\mathrm{CN})_{6}\right]$

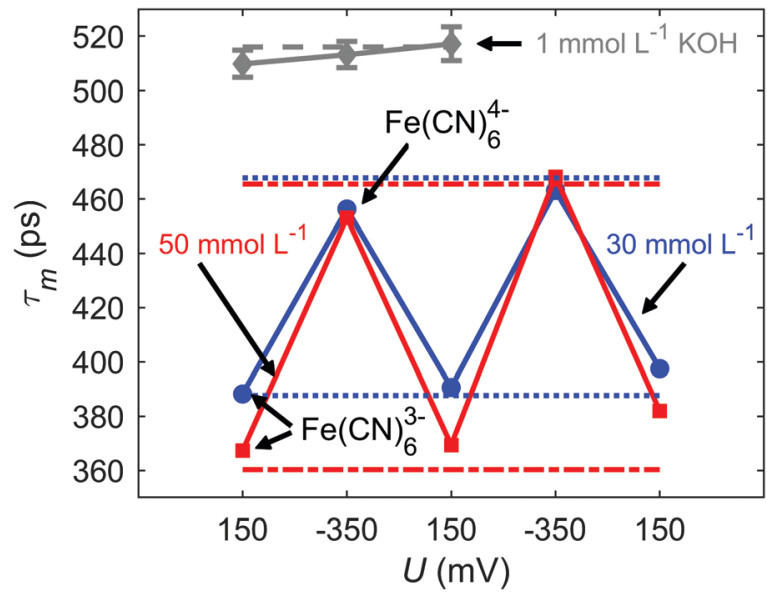

Fig. 3 Mean $\mathrm{e}^{+}$lifetimes $\tau_{\mathrm{m}}$ of $30 \mathrm{mmol} \mathrm{L}^{-1} \mathrm{~K}_{3}\left[\mathrm{Fe}(\mathrm{CN})_{6}\right]$ with $1 \mathrm{mmol} \mathrm{L}^{-1}$ $\mathrm{KOH}$ (blue, circle) and $50 \mathrm{mmol} \mathrm{L}^{-1} \mathrm{~K}_{3}\left[\mathrm{Fe}(\mathrm{CN})_{6}\right]$ with $1 \mathrm{mmol} \mathrm{L}^{-1} \mathrm{KOH}$ (red, square) measured in situ at potentials of $150 \mathrm{mV}$ and $-350 \mathrm{mV}$. According to Fig. 2, $150 \mathrm{mV}$ corresponds to the $\mathrm{Fe}(\mathrm{CN})_{6}{ }^{3-},-350 \mathrm{mV}$ to the already reduced $\mathrm{Fe}(\mathrm{CN})_{6}{ }^{4-}$. For comparison, $\tau_{\mathrm{m}}$-values of ex situ measurements (without applied potential) of $\mathrm{K}_{3}\left[\mathrm{Fe}(\mathrm{CN})_{6}\right]$ and $\mathrm{K}_{4}\left[\mathrm{Fe}(\mathrm{CN})_{6}\right]$ with $1 \mathrm{mmol} \mathrm{L}^{-1}$ $\mathrm{KOH}$ are shown $\left(30 \mathrm{mmol} \mathrm{L}^{-1}\right.$ : blue, dotted line; $50 \mathrm{mmol} \mathrm{L}^{-1}$ : red, dashdotted line). In addition, $\tau_{\mathrm{m}}$-values are plotted for the $1 \mathrm{mmol} \mathrm{L^{-1 } \mathrm { KOH }}$ reference electrolyte measured in situ (gray, diamond) and measured ex situ (gray, dashed line). Unless shown, error bars of the data points are smaller than the marker size.

(468 and $466 \mathrm{ps}$ ) is due to Ps oxidation. The reduction in $\tau_{\mathrm{m}}$ for $\mathrm{K}_{4}\left[\mathrm{Fe}(\mathrm{CN})_{6}\right]$ (468 and $466 \mathrm{ps}$ ) compared to $1 \mathrm{mmol} \mathrm{L}^{-1} \mathrm{KOH}$ (516 ps) is a result of Ps inhibition. ${ }^{11}$ For the in situ measurements, presented next, only the mean $\mathrm{e}^{+}$lifetimes are quoted, since less counts could be recorded per spectrum, but $\tau_{\mathrm{m}}$ can still be determined with high reliability even for reduced statistical accuracy.

At first, static in situ measurements at defined potentials were performed with the electrolyte being either in the $\mathrm{Fe}(\mathrm{CN})_{6}{ }^{3-}(150 \mathrm{mV})$ or the $\mathrm{Fe}(\mathrm{CN})_{6}{ }^{4-}$ state $(-350 \mathrm{mV})$. Fig. 3 shows the mean $\mathrm{e}^{+}$lifetimes $\tau_{\mathrm{m}}$ upon voltage switching between $150 \mathrm{mV}$ and $-350 \mathrm{mV}$ for $\mathrm{K}_{3}\left[\mathrm{Fe}(\mathrm{CN})_{6}\right]\left(30 \mathrm{mmol} \mathrm{L}^{-1}\right.$ : blue, circle; $50 \mathrm{mmol} \mathrm{L}^{-1}$ : red, square) with $1 \mathrm{mmol} \mathrm{L}^{-1} \mathrm{KOH}$ and for the pure $1 \mathrm{mmol} \mathrm{L}^{-1} \mathrm{KOH}$ reference (gray, diamont). Highly reversible changes in $\tau_{\mathrm{m}}$ of about $70 \mathrm{ps}$ for $30 \mathrm{mmol} \mathrm{L}^{-1}$ and 90 ps for $50 \mathrm{mmol} \mathrm{L}^{-1}$ are observed by switching the oxidation state from $\mathrm{Fe}(\mathrm{CN})_{6}{ }^{3-}$ to $\mathrm{Fe}(\mathrm{CN})_{6}{ }^{4-}$ and vice versa. For the

Table 2 Results of ex situ $\mathrm{e}^{+}$lifetime measurements of $1 \mathrm{mmol} \mathrm{L}^{-1} \mathrm{KOH}$ reference solution as well as of $\mathrm{K}_{3}\left[\mathrm{Fe}(\mathrm{CN})_{6}\right]$ and $\mathrm{K}_{4}\left[\mathrm{Fe}(\mathrm{CN})_{6}\right]$ solutions $\left(30 \mathrm{mmol} \mathrm{L}^{-1}\right.$,

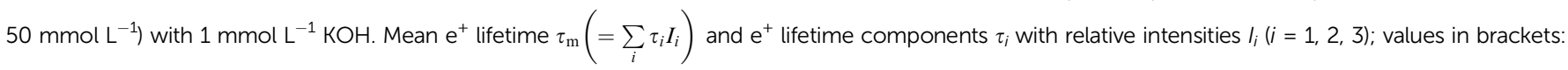
numerical uncertanties; fix: component fixed

\begin{tabular}{|c|c|c|c|c|c|c|c|}
\hline & $\tau_{1}(\mathrm{ps})$ & $I_{1}(\%)$ & $\tau_{2}(\mathrm{ps})$ & $I_{2}(\%)$ & $\tau_{3}(\mathrm{ps})$ & $I_{3}(\%)$ & $\tau_{\mathrm{m}}(\mathrm{ps})$ \\
\hline $30 \mathrm{mmol} \mathrm{L}^{-1} \mathrm{~K}_{4}\left[\mathrm{Fe}(\mathrm{CN})_{6}\right]$ & $210(10)$ & $48.4(7.8)$ & $365(23)$ & $39.3(7.6)$ & $1811(37)$ & $12.3(0.3)$ & $468(3)$ \\
\hline $30 \mathrm{mmol} \mathrm{L}^{-1} \mathrm{~K}_{3}\left[\mathrm{Fe}(\mathrm{CN})_{6}\right]$ & $217(7)$ & $50.3(4.8)$ & $442(28)$ & $41.8(3.7)$ & $1187(80)$ & $7.9(1.3)$ & $388(2)$ \\
\hline $50 \mathrm{mmol} \mathrm{L}^{-1} \mathrm{~K}_{4}\left[\mathrm{Fe}(\mathrm{CN})_{6}\right]$ & $216(8)$ & $54.5(6.1)$ & $392(25)$ & $33.7(5.8)$ & $1832(40)$ & $11.8(0.3)$ & $466(3)$ \\
\hline $50 \mathrm{mmol} \mathrm{L}^{-1} \mathrm{~K}_{3}\left[\mathrm{Fe}(\mathrm{CN})_{6}\right]$ & $226(9)$ & $49.5(6.1)$ & $437(30)$ & $46.3(4.8)$ & $1106(160)$ & $4.2(1.7)$ & $360(1)$ \\
\hline $50 \mathrm{mmol} \mathrm{L}^{-1} \mathrm{~K}_{3}\left[\mathrm{Fe}(\mathrm{CN})_{6}\right]$ & $200(13)$ & $30.4(6.0)$ & $353(11)$ & $57.8(6.0)$ & 789 (11) & 11.8 (fix) & $358(1)$ \\
\hline
\end{tabular}




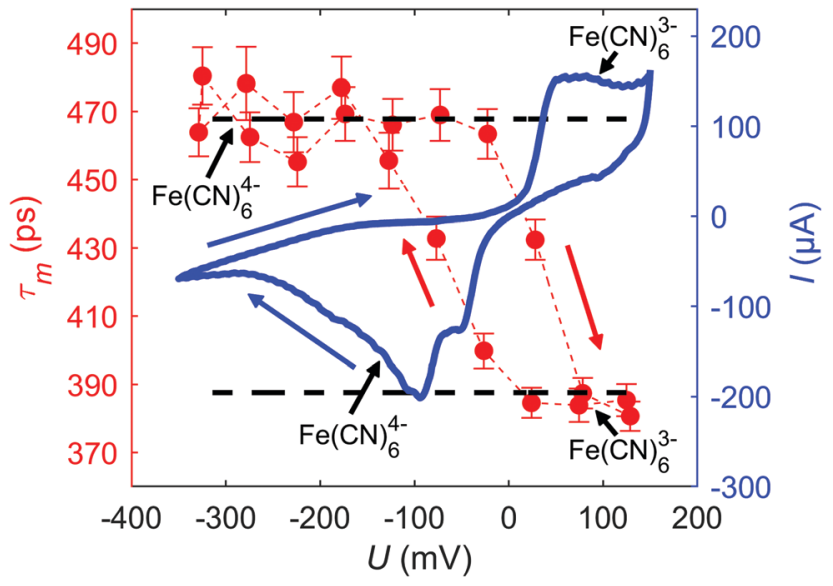

Fig. 4 Dynamic in situ measurement of the mean $\mathrm{e}^{+}$lifetime $\tau_{\mathrm{m}}$ in

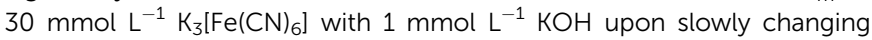
potential $U$ with a rate of $5.6 \mu \mathrm{V} \mathrm{s} \mathrm{s}^{-1}$ between 150 and $-350 \mathrm{mV}$. The simultaneously measured current $I$ is plotted in a cyclic voltammogram (CV). The arrows indicate the scan direction. The ex situ measurements (without applied voltage) of $30 \mathrm{mmol} \mathrm{L}{ }^{-1} \mathrm{~K}_{3}\left[\mathrm{Fe}(\mathrm{CN})_{6}\right]$ and $\mathrm{K}_{4}\left[\mathrm{Fe}(\mathrm{CN})_{6}\right]$, each with $1 \mathrm{mmol} \mathrm{L^{-1 }} \mathrm{KOH}$, are plotted as black, dashed lines, for comparison.

$1 \mathrm{mmol} \mathrm{L}{ }^{-1} \mathrm{KOH}$ reference, only a minor variation of $\tau_{\mathrm{m}}$ within the scope of the error margin occurs upon voltage switching. This clearly demonstrates that the observed switching of $\tau_{\mathrm{m}}$ exclusively results from the $\mathrm{Fe}(\mathrm{CN})_{6}{ }^{3-/ 4-}$ redox couple, i.e., from the switching of Ps triplet quenching which represents the central result of the present work.

The $\tau_{\mathrm{m}}$ values of the in situ and ex situ measurements for both oxidation states match pretty well. The slightly reduced total variation of $\tau_{\mathrm{m}}$ may be due to a slightly incomplete oxidation and reduction since the static positron lifetime measurements were recorded over a time span of several hours, starting upon voltage switching to achieve sufficiently high statistical accuracy. In fact, omitting the initial part of the measurements yield higher $\tau_{\mathrm{m}}$ variations, however, on expense of statistical accuracy. The final reduction (last measurement at $150 \mathrm{mV}$ ) yields clearly longer $\tau_{\mathrm{m}^{-}}$ values of $398 \mathrm{ps}$ for $30 \mathrm{mmol} \mathrm{L}^{-1}$ and $382 \mathrm{ps}$ for $50 \mathrm{mmol} \mathrm{L}^{-1}$ $\mathrm{Fe}(\mathrm{CN})_{6}{ }^{3-}$, as compared to 388 and 367 ps for the initial measurement at $150 \mathrm{mV}$. This deviation may arise from electrolyte degradation, as indicated by a slight turbidity of the electrolyte, perhaps due to a formation of $\mathrm{Fe}^{3+} / \mathrm{Fe}^{2+}$-cyanide colloids or of a small fraction of prussian blue dispersed in the electrolyte. ${ }^{10,21,22}$

Next, dynamic in situ measurements are presented (see Fig. 4). Here, the mean $\mathrm{e}^{+}$lifetime $\tau_{\mathrm{m}}$ is measured for $30 \mathrm{mmol} \mathrm{L}^{-1} \mathrm{~K}_{3}\left[\mathrm{Fe}(\mathrm{CN})_{6}\right]$ with $1 \mathrm{mmol} \mathrm{L}^{-1} \mathrm{KOH}$ in dependence of a slowly changing potential $U$ of $5.6 \mu \mathrm{V} \mathrm{s}^{-1}$ between 150 and $-350 \mathrm{mV}$, simultaneously monitoring the current $I$ as plotted as CV. The dynamic CV in Fig. 4 slightly differs from the CV in Fig. 2 due to the parallel connection of the two sub-cells and the significantly slower scan rate. The mean $\mathrm{e}^{+}$lifetimes in both oxidation states perfectly fit with the ex situ measurements (black, dashed lines) indicating that the entire electrolyte undergoes reduction and oxidation upon cycling. The $\tau_{\mathrm{m}}-U$ variation exhibits a remarkable hysteresis like behavior which exactly resembles the shift between the reduction and oxidation peak according to the $\mathrm{CV}$. Starting in the $\mathrm{Fe}(\mathrm{CN})_{6}{ }^{3-}$ state, upon reduction to $\mathrm{Fe}(\mathrm{CN})_{6}{ }^{4-}$ at around $-90 \mathrm{mV}, \tau_{\mathrm{m}}$ strongly increases. Reversing the scan direction, upon oxidation to $\mathrm{Fe}(\mathrm{CN})_{6}{ }^{3-}$ at around $50 \mathrm{mV}, \tau_{\mathrm{m}}$ strongly decreases to the starting value. The dynamic scan impressively shows that also the region of mixed oxidation state is accessible to positron annihilation yielding $\tau_{\mathrm{m}}$-values in between those of the fully oxidized or reduced state.

\section{Conclusion}

In conclusion, electrochemically controlled positronium triplet quenching in an aqueous electrolyte $\left(\mathrm{K}_{3}\left[\mathrm{Fe}(\mathrm{CN})_{6}\right]\right)$ was for the first time successfully in situ monitored. Switching between two different potentials, corresponding to $\mathrm{Fe}(\mathrm{CN})_{6}{ }^{3-}$ and $\mathrm{Fe}(\mathrm{CN})_{6}{ }^{4-}$ oxidation states, show highly reversible changes in the $\tau_{\mathrm{m}}$ value, which could be associated with Ps oxidation by $\mathrm{Fe}(\mathrm{CN})_{6}{ }^{3-}$. Dynamic measurements allow to exactly correlate Ps annihilation charactersitics with cyclic voltametry. As an outlook, the high sensitivity of the $\mathrm{e}^{+}$lifetime towards already small changes in the oxidation state of the molecules in the electrolyte can be used, e.g., to study the charging/discharging behavior in an iron-based aqueous redox flow battery (IBARFB). In IBA-RFBs the $\mathrm{Fe}^{2+} / \mathrm{Fe}^{3+}$ redox couple is used as the catholyte. ${ }^{28} \mathrm{Fe}^{2+}$ and $\mathrm{Fe}^{3+}$ are known to affect Ps formation and annihilation quite differently, ${ }^{11,13}$ making this application relevant redox couple highly suitable to study the chargingdischarging behavior of the catholyte in IBA-RFBs by in situ positron annihilation. A further field of application would be to change in situ the concentration depending Ps quenching (spin conversion or oxidation) and inhibition behavior of, e.g., $\mathrm{Cu}^{2+}$ ions, ${ }^{29,30}$ by electrochemical means.

\section{Conflicts of interest}

There are no conflicts to declare.

\section{Acknowledgements}

The authors are indebted to Wolfgang Sprengel (Institute of Materials Physics, TU Graz) for technical support and for valuable comments. Furthermore the authors thank Gregor Klinser (former member of the Institute of Materials Physics, TU Graz) for the support during the preparation of the in situ $\mathrm{e}^{+}$ measurements. The work was performed in the framework of the interuniversity cooperation of TU Graz and Uni Graz on natural sciences (NAWI Graz).

\section{Notes and references}

1 P. Harks, F. Mulder and P. Notten, J. Power Sources, 2015, 288, 92-105.

2 S. Topolovec, H. Krenn and R. Würschum, Rev. Sci. Instrum., 2015, 86, 063903. 
3 G. Klinser, H. Kren, S. Koller and R. Würschum, Appl. Phys. Lett., 2019, 114, 013905.

4 O. E. Mogensen, Positron annihilation in chemistry, Springer, 1995.

5 J. Y. Jean, P. E. Mallon and D. M. Schrader, Principles and applications of positron and positronium chemistry, World Scientific, 2003.

6 J. Serna, J. C. Abbe and G. Duplătre, Phys. Status Solidi A, 1989, 115, 389-397.

7 W. Magalhaes, J. C. Abbé and G. Duplâtre, Chem. Phys., 1989, 136, 141-149.

8 G. Duplatre, A. Haessler and J. Abbe, J. Phys. Chem., 1985, 89, 1756-1760.

9 Z. Kajcsos, L. Liszkay, G. Duplâtre, L. Lohonyai, L. Varga, K. Lázár, G. Pál-Borbély, H. Beyer, P. Caullet and J. Patarin, et al., Radiat. Phys. Chem., 2003, 68, 363-368.

10 N. Frenzel, J. Hartley and G. Frisch, Phys. Chem. Chem. Phys., 2017, 19, 28841-28852.

11 G. Duplatre, J. Talamoni, J. C. Abbe and A. Haessler, Radiat. Phys. Chem., 1984, 23, 531-536.

12 A. L. F. Lazzarini and E. Lazzarini, Int. J. Radiat. Appl. Instrum., Part C. Radiat. Phys. Chem., 1990, 36, 377-381.

13 S. Tao, Appl. Phys., 1976, 10, 67-79.

14 A. L. Nichols, R. E. Wild, L. J. Bartal and H. J. Ache, Appl. Phys., 1974, 4, 37-40.

15 E.-M. Steyskal, M. Seidl, M. Graf and R. Würschum, Phys. Chem. Chem. Phys., 2017, 19, 29880-29885.

16 C. Lakshmanan, R. Viswanath, S. Polaki and R. Rajaraman, AIP Conf. Proc., 2015, 140033.
17 S. Cattarin, D. Kramer, A. Lui and M. M. Musiani, J. Phys. Chem., 2007, 111, 12643-12649.

18 D. J. Keeble, U. Brossmann, W. Puff and R. Würschum, Charact. Mater., 2002, 1-28.

19 J. V. Olsen, P. Kirkegaard, N. J. Pedersen and M. Eldrup, Phys. Status Solidi C, 2007, 4, 4004-4006.

20 P. Kirkegaard, J. V. Olsen and M. Eldrup, PALSfit3: A software package for analysing positron lifetime spectra, Technical University of Denmark, 2017.

21 A. Abbaspour and M. A. Kamyabi, J. Electroanal. Chem., 2005, 584, 117-123.

22 R. Yang, Z. Qian and J. Deng, J. Electrochem. Soc., 1998, $145,2231$.

23 R. G. Compton and C. E. Banks, Understanding voltammetry, World Scientific, 2018.

24 Y. Iwasaki, T. Horiuchi, M. Morita and O. Niwa, Surf. Sci., 1999, 427, 195-198.

25 C. Beling and F. Smith, Radiat. Phys. Chem., 1984, 23, 571-577.

26 G. Duplatre, J. C. Abbé, J. Talamoni, J. C. Machado and A. Haessler, Chem. Phys., 1981, 57, 175-183.

27 P. Stepanov, F. Selim, S. Stepanov, A. Bokov, O. Ilyukhina, G. Duplâtre and V. Byakov, Phys. Chem. Chem. Phys., 2020, 22, 5123-5131.

28 H. Zhang and C. Sun, J. Power Sources, 2021, 493, 229445.

29 P. De Natale, A. Dupasquier, A. Fantola-Lazzarini, E. Lazzarini and A. Rolando, Il Nuovo Cimento D, 1993, 15, 1215-1228.

30 B. Ganguly, V. Subrahmanyam and P. Sarkar, J. Radioanal. Nucl. Chem., 1994, 181, 201-209. 